case there is no need to drop the use of "envelope" in relation to core if we do decide also to use "fold-envelope"; for in context, where the former will relate to one fold and the latter to a set, there can never be any confusion between them.

Where, as frequently occurs, fold axial planes are inclined to the fold envelope, and in consequence the limbs are alternately long and short, the folds are obviously asymmetric. The existence of such asymmetry may be highly significant. The obvious name for this important class of folds which includes, for instance, drag folds due to shearing movements, is " asymmetrical folds". This is, indeed, the name used by Stočes and White (1935) and by Turner and Weiss (1963). In a footnote to his paper, Dr. Fleuty mentions this usage, but he nevertheless recommends the continued use of the term as descriptive of the attitude of a fold in space. Used in this way (for a fold with inclined axial plane and limbs dipping in opposite directions) the term is certainly widely known. But this is one of those terms, beloved of a certain type of examiner, which because they convey only a meaningless distinction are practically never encountered except in text-books. Thus it is a thoroughly bad case of the pre-empting of a useful word for a special case to the detriment of its use in more suitable ways. I should like to recommend that authors and editors accept the definition of Turner and Weiss and reject the original definition, which, they will find, "never will be missed".

\title{
REFERENCES
}

Fleuty, M. J., 1964. The descriptions of folds. Proc. Geol. Assoc., 75, 461-492.

Stočes, B., and C. H. White, 1935. Structural Geology. London.

TURner, F. J., and L. E. WeIss, 1963. Structural Analysis of Metamorphic Tectonites. New York.

DEPARTMENT OF GEOLOGY,

UNIVERSITY OF EXETER.

5th January, 1965.

\section{APPINITES IN THE CALEDONIDES}

SIR,-The use by Dr. Janet Watson of the appinite suite in a discussion of "Conditions in the Metamorphic Caledonides during the period of Lateorogenic Cooling " (Geol. Mag., 101, 457-465, 1964) requires further examination, particularly with regard to the relationship of this suite to the large Caledonian granite masses and the correlation of the appinites of the Southwestern Highlands and with the Ach'uaine hybrids of the Northern Highlands.

The small pipe-like intrusions of the appinites in the S.W. Highlands were formed prior to and unconnected with the emplacement of the granitic plutons of the district. This is clear from the composition of xenoliths, crosscutting relations on both regional and local scales and the time separation shown by intervening lamprophyre intrusion (Bailey, E. B., and H. B. Maufe, 1960, Mem. geol. Surv. Scot., Sheet 53-2nd. ed., 188, 212, 259; Bowes, D.R., 1962, Geol. Mag., 99, 119-122). There is considerable evidence to suggest that the appinite association is both basaltic and volcanic. As well as the basaltic and lamprophyric chilled margins, as mentioned by Dr. Watson (p. 461), their chemistry is indicative of alkali basalt composition and their mineralogy indicative of crystallisation of basic magma under conditions of variable water vapour pressure (Bowes, D. R., E. D. Kinloch, and A. E. Wright, 1964, Miner. Mag., 33, 969-972). The appinites form pipe-like intrusions into explosion pipes (e.g. Bowes, D. R., and A. E. Wright, 1961. Trans. Edinb. geol. Soc., 18, 293-314) and both in chemistry (Walker, F., 1927, Trans. roy. Soc. Edinb., 55, 154) and in age relations, there is a close connection between the appinites and the Lorne and Glen Coe Lavas.

There is evidence of association with explosive activity in rocks in the Northern Highlands which, in composition, texture and mineralogical characteristics, are comparable with the appinites from their type area in the 
S.W. Highlands. Large idiomorphic amphibole phenocrysts, with rhythmic amphibole overgrowths, indicating the formation of explosion-breccias, at some level, are present in such appinitic types on Cnoc a Ghriama, $2 \frac{1}{2}$ miles W.N.W. of Overscraig Hotel, Loch Shin, Sutherland. These rocks have the characteristics of a basaltic, volcanic association and show no features suggesting a granitic association or hybrid origin.

As Dr. Watson points out (p. 461), the Ach'uaine hybrids are not associated with explosion-breccias, but these hybrids cannot be considered to be " the corresponding intrusions within the central part of the fold belt" (p. 461) to the appinites in the S.W. Highlands. Any implication that these appinites must be closely associated with the Caledonian granite masses because this is the association of the Ach'uaine hybrids cannot be accepted. However, the association of a thick early Devonian volcanic pile and appinite pipes in the S.W. Highlands suggest the possibility of a corresponding volcanic pile in the Northern Highlands associated with the appinites of Cnoc a Ghriama and other places. The existence of such a volcanic pile during the emplacement of the Caledonian granites could be a significant factor in the cooling history of the area.

Department of Geology,

D. R. BOWES.

THE UNIVERSITY,

GLASGOW, W.2. (D.R.B., T.S.G.)

DEPARTMENT OF GEOLOGY,

Tharwat S. GHaly.

THE UNIVERSITY,

Birmingham, 15. (A.E.W.) 